\title{
WestVirginiaUniversity
}

THE RESEARCH REPOSITORY @ WVU

Graduate Theses, Dissertations, and Problem Reports

2019

\section{Review of water allocation models for West Virginia}

Madison Lee Alexis Thompson

mthompson@mix.wvu.edu

Follow this and additional works at: https://researchrepository.wvu.edu/etd

Part of the Civil Engineering Commons, and the Hydraulic Engineering Commons

\section{Recommended Citation}

Thompson, Madison Lee Alexis, "Review of water allocation models for West Virginia" (2019). Graduate Theses, Dissertations, and Problem Reports. 7441.

https://researchrepository.wvu.edu/etd/7441

This Problem/Project Report is protected by copyright and/or related rights. It has been brought to you by the The Research Repository @WVU with permission from the rights-holder(s). You are free to use this Problem/Project Report in any way that is permitted by the copyright and related rights legislation that applies to your use. For other uses you must obtain permission from the rights-holder(s) directly, unless additional rights are indicated by a Creative Commons license in the record and/ or on the work itself. This Problem/Project Report has been accepted for inclusion in WVU Graduate Theses, Dissertations, and Problem Reports collection by an authorized administrator of The Research Repository @ WVU. For more information, please contact researchrepository@mail.wvu.edu. 


\title{
Review of water basin models for West Virginia \\ Madison L. Thompson
}

\author{
Problem report submitted to the \\ Benjamin M. Statler College of Engineering and Mineral Resources \\ at West Virginia University \\ in partial fulfillment of the requirements for the degree of
}

Masters of Science

in

Civil and Environmental Engineering

Leslie Hopkinson, Ph.D., Chair

Seungho Hong, Ph.D.

John Quaranta, Ph.D., P.E.

Department of Civil and Environmental Engineering

Morgantown, West Virginia

2019

Keywords: West Virginia, RiverWare, StateMod, SWAM, OASIS, Aquarius, river basin modeling

Copyright 2019 Madison L. Thompson 


\section{ABSTRACT \\ Review of water basin models for West Virginia \\ Madison L. Thompson}

Modeling river basins started gaining in popularity and usage in the western part of the United States in large part due to its extreme droughts. Planning is necessary to sustain the population, industries, and recreational water use year-round. Water allocation modeling is a tool used to aid in the issues that come from managing water resources. This work considers the continuous models that synthesized the hydrologic processes that occur and provides a simulation of past, current, or future conditions.

West Virginia, located on the eastern side of the United States, does not have an extreme drought problem as seen in the west. However, its proximity to Washington D.C. provides expanding urban sprawl into the state and subsequently potential demand of water resources. Industrial usage of water from natural gas and coal is heavy within the region as well, providing more stakeholders to the system. This report analyzes six water allocation tools: RiverWare, StateMod, Simplified Water Allocation Model (SWAM), OASIS, Aquarius, and Modsim-DSS. Capabilities of the models were compared, and recommendations were developed for use in West Virginia. A conceptual model based on available model inputs was develop for the Tygart Valley watershed. Results will provide knowledge for the development of watershed and state-wide water allocation modeling in West Virginia. 


\section{ACKNOWLEDGMENTS}

The author wishes to express gratitude to all those who supported her in any respect during the completion of this report.

I wish to first extend special thanks to Dr. Hopkinson, my academic advisor, for her immense guidance and technical expertise.

Sincere thanks are also extended to Dr. John Quaranta and Dr. Seungho Hong for serving as members of my Advisor and Examining Committee.

I am also in deep gratitude to Cate Schlobohm and Ryan Sigler from the office of Outreach and Recruitment for providing assistantship through the completion of my masters.

And last but not least I owe my deepest gratitude to my family, friends, and Jared Bartrug for their constant support and words of encouragement during the completion my masters.

The project described in this publication was supported by Grant/Cooperative Agreement Number G16AS0017 from the United States Geological Survey. Its contents are solely the responsibility of the authors and do not necessarily represent the official views of the USGS. 
Table of Contents

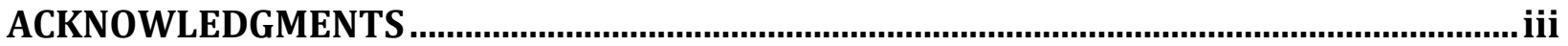

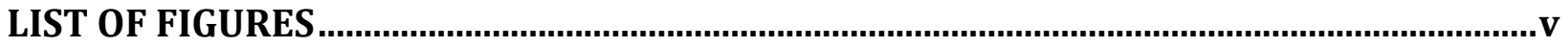

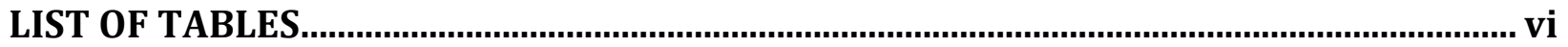

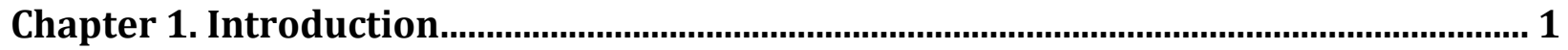

1.1 River basins and the benefits of modeling. ............................................................ 1

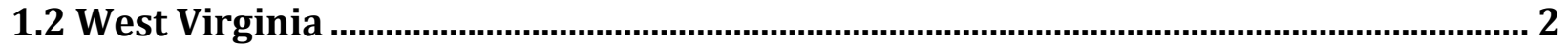

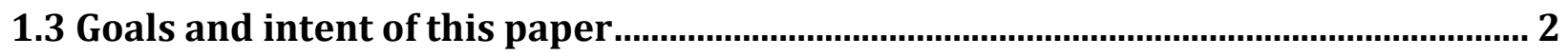

Chapter 2. Applying water allocation modeling to West Virginia..................................... 3

2.1 Water allocation model review ......................................................................................... 3

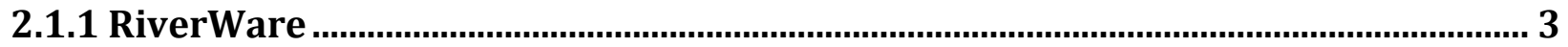

Table 1. Basic features of RiverWare ............................................................................ 4

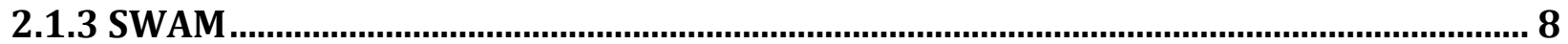

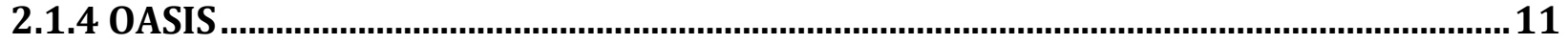

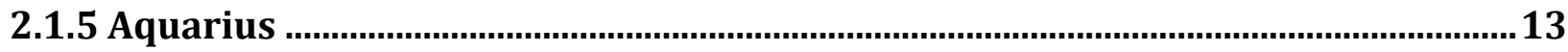

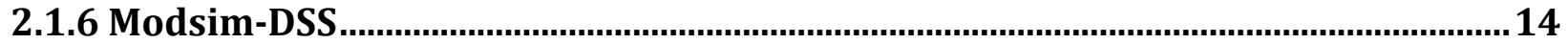

2.2 Case Studies and Applications ................................................................................ 14

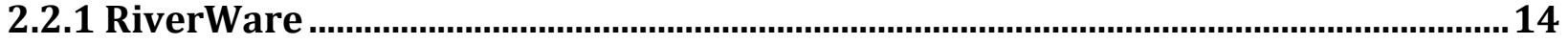

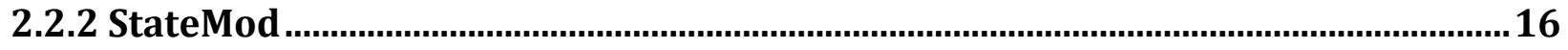

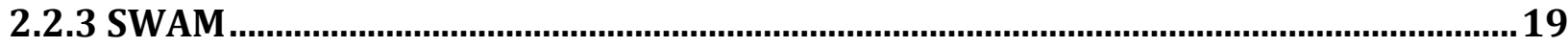

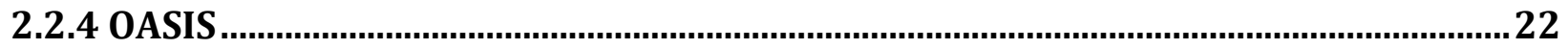

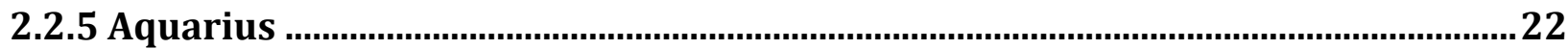

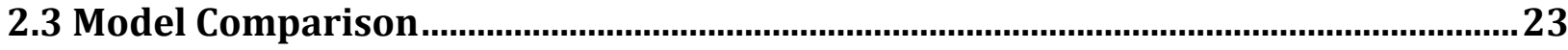

Chapter 3. Model Selection and Application for West Virginia ........................................26

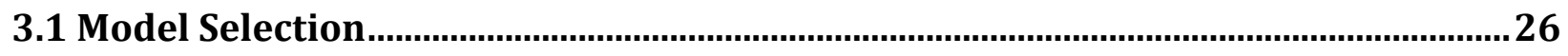

3.2 Application of RiverWare to West Virginia................................................................27

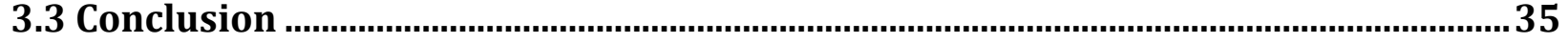

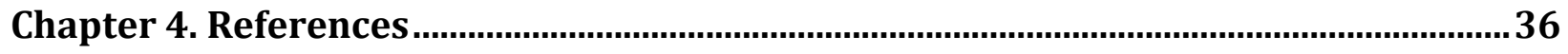

APPENDIX 


\section{LIST OF FIGURES}

Figure 1. Tygart Valley Watershed................................................. 34

Figure 2. Representation of data flow for RiverWare software $\ldots \ldots \ldots \ldots \ldots \ldots \ldots \ldots \ldots \ldots \ldots$ 


\section{LIST OF TABLES}

Table 1. Basic features of RiverWare........................................................ 4

Table 2. Advanced features of RiverWare .............................................. 5

Table 3. Key components and features of StateMod......................................... 7

Table 4. SWAM Model Objects......................................................... 9

Table 5. SWAM Model Outputs...................................................... 10

Table 6. OCL Simulation Commands...................................................... 12

Table 7. RiverWare case study applications............................................. 16

Table 8. Phase I of Colorado River Water availability study water availability assessment..... 18

Table 9. Phase I of Colorado River water availability study 2040 and 2070 projections......... 18

Table 10. Model inputs for the Edisto River Basin.......................................... 20

Table 11. Model inputs for the Saluda River Basin Model................................... 21

Table 12. Model comparison of features.................................................. 24

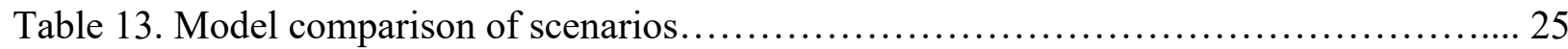

Table 14. Large quantity users in Tygart Valley watershed................................... 29

Table 15. Sources of data available for West Virginia........................................ 31

Table 16. USGS Tygart Valley watershed data availability of daily discharge data.............. 32

Table 17. USGS Tygart Valley watershed collection sites data............................... 33 


\section{Chapter 1. Introduction}

\subsection{River basins and the benefits of modeling.}

River basins are inherently a complex system; they involve streams, reservoirs, canals, aquifers, cities, water users, irrigation districts, and farms just to name a few. Maintaining the functionality of a river basin with different industries, water users, and the natural cycle needs becomes more intense the more human interaction there is with the river basin. The ability to plan for the future continues to expand as the data and technical knowledge of river basins develops (Dinar et al. 2007).

Water allocation software is a tool that can be used to plan for the future in the construction of fair and impartial water sharing agreements and operational rules. The versatility of water allocation software allows for multiple scenarios: past, present, and future. Historical data can be used as calibration for current or future conditions in the basin when available. Future conditions in a river basin model can consider the effects of climate change, industry presence, or changes in population in the region, with each stakeholder creating a different demand on the water source. In areas where there is continuous development and economic growth, it is reasonable to expect increased demand on the water resources available. This increased demand does not always mean that there will be scarcity of the resource; however, it provides potential for the situation. Competition among industries combined with continuously changing environmental standards and expectations adds strain to this delicate relationship. The versatility of water allocation modeling is vast, and with a variety of models available the needs for each basin and study has the potential to be met (Dinar et al. 2007, George et al. 2019).

To meet the specific needs for an area under study for water allocation, the software requires a set of data. Similar to other simulations, the more accurate and extensive the data source(s) are the better the results will be. Each software is different, as will be shown in the subsequent chapters, however in general data on precipitation, water users, stream gauges, river reaches, and control points are needed. This information can come from the U.S. Geological Survey (USGS), U.S. Army Corp. of Engineers, and the EPA, though it is not restricted to just these sources. 


\subsection{West Virginia}

The state of West Virginia is located in the Appalachian region of the southern United States with a humid subtropical climate covering the majority of the state. In the more mountainous region, there is an oceanic and warm-summer humid continental climate. The diversity of climatic conditions within the state are in part due to its topography, being the highest average elevation state east of the Mississippi River. Similar to other states, flooding is a problem that is dealt with every year, threatening riverfront communities with heavier storms. To aid in combating this issue there are dams in place. There are 586 total dams in West Virginia, which includes different owner types: private, local, state, and federal. With privately owned dams it can be either individuals or private companies. The local, state, and federal government owned dams are through government entities such as the Division of Highways, Department of Natural Resources, cities, Corps of Engineers, and United States Forest Service. Even with these flood control structures there is not always the capability to contain and prevent all flood events (USEPA 2016, USACE 2019).

West Virginia is unique is a few ways. It is water rich and receives large portions of rainfall coupled with changing climate patterns of more extreme weather events. There is an increasing population in certain urban areas of the state, as well as D.C. expanding its suburbs further into the eastern panhandle as it also experiences in increasing population. On the other side of this, there is a decreasing population in some of the older communities and less populated regions. Industries such as coal and unconventional oil and gas requires a water source as well. All of these water users and demands have a direct effect on the water supply in the state, and with a changing population, industries, and climate it will be important to plan accordingly to consistently meet the needs of the state's water usage (O'Leary 2019).

\subsection{Goals and intent of this paper}

The goal of this paper is to review water allocation models and the applications for West Virginia, specifically the Tygart Valley Watershed. The intent is to further review future water needs and security for the state and provide knowledge for future planning. 


\section{Chapter 2. Applying water allocation modeling to West Virginia}

\subsection{Water allocation model review}

Water allocation models provide government agencies, private landowners, companies, and other stakeholders to have the capacity to plan for the future in the creation of impartial water sharing agreements and operational rules for current conditions or future scenarios. Through the collection and input of hydrological data, a comprehensive and accurate model can be achieved. In this section six models and their key features, components, abilities, and outputs will be discussed: i) RiverWare, ii) StateMod, iii) Simplified Water Allocation Model (SWAM), iv) OASIS, v) Aquarius, and vi) MODSIM-DSS.

\subsubsection{RiverWare}

RiverWare is a modeling tool that allows the user to create and customize any basin to facilitate simulation or optimization to help schedule, project, and plan for that basin. During the build phase of the basin model, the user can select different processes on a more generic or specific basis. Some of the more basic features available in RiverWare for its physical processes are storage reservoir, power reservoir, slope power reservoir, pump storage reservoir, inline pump/generator, river reach, confluence, river gage, water uses, AggDiversions, diversions, aggregate delivery canal, groundwater storage, canal, thermal object, and data object (table 1). The program is meant for short-term operations and development, mid-term procedures and planning, and long-term policy and planning (Parker et al. 2006, RiverWare 2015). 
Table 1. Basic features of RiverWare

\begin{tabular}{|c|c|}
\hline Feature Name & Feature Description \\
\hline Storage Reservoir & $\begin{array}{l}\text { Calculates mass balance, including evaporation, precipitation and bank } \\
\text { storage, releases, regulated and unregulated spill; and sediment accumulation. }\end{array}$ \\
\hline Power Reservoir & $\begin{array}{l}\text { Calculates storage reservoir processes plus turbine releases, hydropower and } \\
\text { energy and tailwater elevation. }\end{array}$ \\
\hline Slope Power Reservoir & $\begin{array}{l}\text { Calculates storage and power reservoir processes plus wedge storage reservoir } \\
\text { routing. }\end{array}$ \\
\hline Pump Storage Reservoir & Calculates power reservoir processes plus pumping power and energy. \\
\hline Inline Pump/Generator & Calculates pumping/generating power and energy and turbine/pump flow. \\
\hline River Reach & Routes flow and calculates gains and losses. \\
\hline Confluence & Calculates mass balance at a river confluence. \\
\hline River Gage & Reflects measured or forecasted flows. \\
\hline Water Users & $\begin{array}{l}\text { Calculates depletion (consumption), groundwater and surface water return } \\
\text { flow. }\end{array}$ \\
\hline AggDiversions & Aggregates water users and models simple diversions. \\
\hline Diversion & Models gravity or pumped diversion structure. \\
\hline Aggregate Delivery Canal & Models off-line delivery canals. \\
\hline Groundwater Storage & Models temporary aquifer storage for return flows. \\
\hline Canal & Models bi-directional flow between reservoirs. \\
\hline Thermal Object & Represents economics of hydropower in total hydro/thermal power systems. \\
\hline Data Object & Evaluates user-defined expressions. \\
\hline
\end{tabular}

Source: RiverWare 2015

RiverWare goes beyond just the basic features described in the table above. Its capabilities extend so that the different stakeholders for a given basin are not only satisfied in the software to make their own water management decisions but also to create trust in potentially argumentative situations with other stakeholders. Having the same model with the specific functions needed for each stakeholder allows for all parties to see what happens under different scenarios. Additional features within the program (table 2) are also available and have more 
advanced capabilities as compared to the basic features (table 1) (Zagona et al. 2001).

Table 2. Advanced features of RiverWare

\begin{tabular}{|l|l|}
\hline Feature Name & Feature Description \\
\hline Data Management Interface & $\begin{array}{l}\text { Provides the ultimate flexibility to share data with other applications and } \\
\text { analysis tools, other agencies, and other system users. }\end{array}$ \\
\hline Multiple Run Management & Set up multiple model runs at the same time and change data inputs or policies. \\
\hline Advanced Diagnostics & $\begin{array}{l}\text { Improve the analysis of the model runs through the printing of informational } \\
\text { messages on slots, time steps, methods, controllers, and specified objects. This } \\
\text { helps to diagnose exact problems. }\end{array}$ \\
\hline Sub basins & $\begin{array}{l}\text { This feature allows for several users to schedule different sub basins as } \\
\text { variables. }\end{array}$ \\
\hline Snapshot Manager & $\begin{array}{l}\text { Allows for automatic saving of inputs and outputs of model run to be later } \\
\text { compared to other model runs. }\end{array}$ \\
\hline Output Options & The unlimited plotting of variables from successive model runs. \\
\hline Batch Mode & $\begin{array}{l}\text { Allows for work to be done via a modem. User can make a run, enter data, and } \\
\text { look at data in batch mode. }\end{array}$ \\
\hline
\end{tabular}

Source: RiverWare 2015

This software provides three different types of solvers within the program. They include rule-based simulation, pure simulation, and optimization. Rule-based simulation is driven by ifthen-else operating policies input by the users. This is a predicting technique that is used for forecasting the effects of changing inflows and demands on the system given the operational rules. These rules are written in a language provided through an editor. One of the more valuable benefits of the rule-based simulation is that the rules are representative of policies that are seen as dynamic data. This viewpoint allows for the data to be modified outside the code that has been compiled (RiverWare 2015).

Pure simulation solve is algorithms that solves for things like reservoir storage, turbine discharge, or pool elevations as inputs to initiate the simulation. The capabilities with this type of solver allows for meeting the future needs of storage or even solving for the amount of upstream releases to meet the needs of downstream demands (Macpherson 2016).

Optimization is driven by a set of prioritized goals that allows for trading off multiple objectives. These multisystem objectives include flood control, water supply, navigation, 
recreation, hydropower production, and fish and wildlife habitat. Optimization works through a linear program (LP) which prioritizes policy objects and constraints. Once the order of priority is set, the best solution is given based on the given prioritized goals (Macpherson 2016).

\subsubsection{StateMod}

StateMod is the state of Colorado's Stream Simulation Model which does daily or monthly water allocation as well as historical and future water management policies for a river basin. It is also able to simulate a stream diversions, well pumping, reservoir operations, and instream demands based on the features (table 3) the program provides. This program operates similar to a stream and is run based on the water rights, hydrology, and operating rules. Within StateMod it recognizes water rights as direct flow rights, instream flow rights, reservoir storage flow rights, well rights, and operational rights. These rights are given a ranking and location within the stream system and it is then sorted using the logic of first in time, first in right, also known as the Prior Appropriation Doctrine. This is simulated under Colorado's Prior Appropriation water law. The software is meant for any river basin given the appropriate information. Some of the key components to input and use for a river basin are outlined below (Nature Conservancy 2018, Colorado DNR 2019). 


\section{Table 3. Key components and features of StateMod}

\begin{tabular}{|c|c|}
\hline Features & Features Description \\
\hline Daily or Monthly Time Step & $\begin{array}{l}\text { Provides daily data through monthly averages, a monthly divide by the number of } \\
\text { days in a month, or through the use of monthly data and another gages daily } \\
\text { distribution. }\end{array}$ \\
\hline Network System & $\begin{array}{l}\text { Uses a tree structured network system to simulate tributaries and main stem river } \\
\text { systems. }\end{array}$ \\
\hline Prior Appropriation Doctrine & $\begin{array}{l}\text { In a function of water availability, priority, decreed amount, demand, structure, } \\
\text { capacity, and location. }\end{array}$ \\
\hline Operational Rules & Operational agreements and exchanges between one or more structures \\
\hline Return Flows & $\begin{array}{l}\text { Simulates one or more return flow patterns returning to one or more stream nodes } \\
\text { to represent the impact of surface and groundwater returns on stream. }\end{array}$ \\
\hline Instream Flows & Has instream flow as a reach or point. \\
\hline Wells & Shows as a source of water or as a supplemental supply. \\
\hline Plans & $\begin{array}{l}\text { Represents terms and conditions associated with reusable water supplies, a water } \\
\text { transfer, or out-of-priority well pumping. }\end{array}$ \\
\hline Base or Natural Flows & $\begin{array}{l}\text { The base or natural flow based on gage or estimated streamflow, reservoir data, } \\
\text { and diversion. }\end{array}$ \\
\hline $\begin{array}{l}\text { Modified Direct Solution } \\
\text { Algorithm }\end{array}$ & $\begin{array}{l}\text { Allows for current time step return flows, soil moisture accounting, and variable } \\
\text { efficiency to be evaluated without having to iterate. }\end{array}$ \\
\hline Variable Efficiency & An average or variable efficiency that simulates water use. \\
\hline Soil Moisture Accounting & Soil inflow, use, and storage is simulated. \\
\hline Transmountain Diversions & Transmountain diversions and imports from a basin. \\
\hline Call Reporting & Estimates the calling right and structure. \\
\hline Graphical User Interface & $\begin{array}{l}\text { Output data can be graphed and viewed as well as map representation of the } \\
\text { basin, hydrology, and structure location. }\end{array}$ \\
\hline Data Centered Approach & A direct link to HydroBase to make it easier to refresh for a new study period. \\
\hline Error Checking & Done extensively throughout the program. \\
\hline
\end{tabular}

Source: Colorado DNR 2019

One of the biggest strengths for StateMod is its integration with a database of hydrologic data, HydroBase. It's best when the data is heavily based on this database, has an agricultural focus, and has a generation of base flows. Its operational flexibility lies with its use of a modified 
priority system that intertwines water right administration numbers and operating rule order. Input data consists of a river network definition, stations or nodes (stream gage, diversion, reservoirs, and wells), and the data related to stations such as water rights and time series. The output data is binary files with large text file reports, log and check files, and time series data, all depending on the run options (Macpherson 2016).

\subsubsection{SWAM}

The Simplified Water Allocation Model (SWAM) was created to have a more simplified and efficient water allocation tool to apply for different planning studies and a variety of users, starting specifically with South Carolina. Similar to many other water allocation tools, SWAM calculates diversions, storage, consumption, return flows, and physically and legally available water and is defined through nodes in the river system. The types of water uses can be defined in this model by municipal water suppliers, agricultural irrigators, and industrial water users. This model is meant to add layers of complexity based on the user's needs, starting with a very simple basis and developing into more complex (Smith 2017E).

Within SWAM there are model objects (table 4), which are elements that are userconstructed in a network of streams, reservoirs, and water use nodes. Each of these model objects has its own set of equations and user inputs that will help to calculate the outputs. The model outputs are as follows: Tributaries, Dischargers, Reservoirs, Water Users, Agricultural Users, Instream Flow Objects, Recreation Pool Objects, Aquifer Objects, and Flow Gages. Within each model object there are also different parameters associated with them, although some do not have specific parameters (South Carolina DNR 2019). 
Table 4. SWAM Model Objects

\begin{tabular}{|c|c|}
\hline $\begin{array}{l}\text { Model Object } \\
\text { Name }\end{array}$ & Model Object Description \\
\hline Tributaries & $\begin{array}{l}\text { Reach specific parameters that are used during model calibration. Flow changes are also } \\
\text { calculated here. }\end{array}$ \\
\hline Dischargers & $\begin{array}{l}\text { Represent any kind of point discharge to the river basin and can also include wastewater } \\
\text { treatment facility and industrial discharges. }\end{array}$ \\
\hline Reservoirs & $\begin{array}{l}\text { Defines only the physical characteristics of the total reservoir which includes storage } \\
\text { capacity, spatial location, dead pool storage, surface area, and seepage losses. This can be } \\
\text { defined in simple and advanced. }\end{array}$ \\
\hline Water Users & $\begin{array}{l}\text { Most general and versatile tool available. It can represent single or aggregated municipal, } \\
\text { industrial, and/or agricultural irrigation user. }\end{array}$ \\
\hline Agricultural Users & $\begin{array}{l}\text { Defines the water use explicitly based on the demands associated with crop agriculture. } \\
\text { There are seven coefficients for different crop types (corn, wheat, alfalfa, pasture, potatoes, } \\
\text { grains, and beans. }\end{array}$ \\
\hline Instream Flow & Puts priority on environmental and recreational goals in terms of stream flows. \\
\hline Recreation Pool & $\begin{array}{l}\text { Water is diverted or retained in order to keep a user-specified volume of water in the given } \\
\text { reservoir. It is generally for recreation use but can be for hydropower. }\end{array}$ \\
\hline Aquifer & $\begin{array}{l}\text { Track groundwater storage that is subject to pumping by either single or multiple users. } \\
\text { Calculations can be calculated or prescribed. }\end{array}$ \\
\hline Flow Gages & $\begin{array}{l}\text { These provide the streamflow output at specified locations. There are no calculations or } \\
\text { impacts to other parts of the model, rather is associated with a flow gage object, the target } \\
\text { stream, and mile marker location. }\end{array}$ \\
\hline
\end{tabular}

Source: South Carolina DNR 2019

Within SWAM there are also model outputs (table 5). These are monthly outputs for all of the model nodes and are written to the "Node Output" worksheet in SWAM. If there are multiple sources of water for a water user or agricultural user object, then the model creates a detailed output for each individual source as well as summation for the object. The model outputs available for SWAM are the following: physically available, legally available, demand, diverted (prior appropriations) or river withdrawn (riparian), storage/reservoir withdrawal, storage, GW pumping/groundwater withdrawal, shortage, return flow, release, evaporation loss, storage, excess volume, overflow, total inflow, total withdrawn, regulated release, additional outflow, and evaporation (South Carolina DNR 2019). 
Table 5. SWAM Model Outputs

\begin{tabular}{|c|c|}
\hline Model Outputs Name & Model Outputs Description \\
\hline Physically Available & $\begin{array}{l}\text { Calculated as a function of the upstream water flows, node return flows, and node } \\
\text { diversions. }\end{array}$ \\
\hline Legally Available & $\begin{array}{l}\text { A function of downstream priority demands, annual storage rights, physical flows, } \\
\text { and node monthly diversion and/or withdrawal rights in the system. }\end{array}$ \\
\hline Demand & $\begin{array}{l}\text { Solved through user-input or calculated monthly usage values and reuse and } \\
\text { conservation impacts. It is the net water usage demand on the system for a node at } \\
\text { a given time step. }\end{array}$ \\
\hline $\begin{array}{l}\text { Diverted or River } \\
\text { Withdrawal }\end{array}$ & The amount diverted or withdrawn from a specific node at a given timestamp. \\
\hline $\begin{array}{l}\text { Storage/Reservoir } \\
\text { Withdrawal }\end{array}$ & $\begin{array}{l}\text { This is only applicable for storage withdrawal permits. It is the monthly or daily } \\
\text { withdrawals from storage. }\end{array}$ \\
\hline Storage & $\begin{array}{l}\text { It is a function of diverted inflow and demand withdrawals, regulated outflows, } \\
\text { and evaporation losses. This is only applicable for storage account systems. }\end{array}$ \\
\hline $\begin{array}{l}\text { GW Pumping/Groundwater } \\
\text { Withdrawal }\end{array}$ & The monthly rate for pumping groundwater within a given node. \\
\hline Shortage & $\begin{array}{l}\text { What the difference between demand and demand met is. It is the monthly } \\
\text { shortfall in water supply. }\end{array}$ \\
\hline Return Flow & $\begin{array}{l}\text { User-input consumptive use percentages and actual demand left are calculated in a } \\
\text { function to produce return flow. If applicable, reuse considerations are also } \\
\text { incorporated. }\end{array}$ \\
\hline Release & $\begin{array}{l}\text { Only applicable for prior appropriation water law with storage account systems. It } \\
\text { is a monthly return to the stream after node use. }\end{array}$ \\
\hline Evaporation Loss & $\begin{array}{l}\text { This is daily or monthly evaporation loss relating to water user storage accounts } \\
\text { and is only applicable for prior appropriations simulations. }\end{array}$ \\
\hline
\end{tabular}

Source: South Carolina DNR 2019

Other applications of SWAM include water exchanges with two water supply accounts.

Within SWAM, a water exchange is shown as an agreement where an upstream diversion account can divert water but only if the downstream partner account releases the same amount of water within the same timestamp. The program calculates the legally and physically available water at the upstream node but then constraints it to just legally available flow to the total available for release at the downstream account partner. This program can also deal with multibasin water users in which water users are accessing and discharging water in multiple river basins (South Carolina DNR 2019). 
SWAM is a water allocation model that simulates water being moved from the upstream to downstream, routes water through reservoirs, and allocates water to different water user nodes. Its intended purpose is for river basins and like other water allocation models it cannot perform rainfall runoff or reach routing (Streamlined Environmental 2019).

\subsubsection{OASIS}

OASIS is a program for modeling water resource systems and their operations through mass balance. It is advertised as not being just a generalized program, but one that can model any water system in the world. The program has applications in Water Supply, River Basin Management, Hydropower, and Conflict Resolution. It evolved from HydroLogics which shaped the advantages of OASIS. The manual promotes flexibility, standardized features, realistic forms for operating rules, integrating with other models, database storage, and graphical user interface. The program contains the feature operations control language (OCL) (table 6), which enables the modeler to write rules using various simulation commands while never having to modify the source code. Through its standard features it allows users to model in a more generalized way, and with OCL users can create more specific models at the cost of more time (HydroLogics OASIS 2019). 
Table 6. OCL Simulation Commands

\begin{tabular}{|c|c|}
\hline $\begin{array}{l}\text { OCL Simulation } \\
\text { Commands }\end{array}$ & OCL Command Definitions \\
\hline Udef & Creation of a new variable, can be either decision or non-decision. \\
\hline Segment & $\begin{array}{l}\text { A new decision variable that is a segment of another decision variable. Constraints are } \\
\text { placed so that the summation of the segments is equal to the original variable. }\end{array}$ \\
\hline Set & $\begin{array}{l}\text { Used to assign a value to a non-decision variable based on an evaluated expression the user } \\
\text { provides. }\end{array}$ \\
\hline Constraint & Used for user-defined operating constraint(s) based on at least one decision variable. \\
\hline Target & $\begin{array}{l}\text { User defined constraint or operation goal. (see below for differences between constraint and } \\
\text { target command.) }\end{array}$ \\
\hline Minimax & $\begin{array}{l}\text { User defined operating goal of making two or more user-defined variable quantities equal } \\
\text { to each other. }\end{array}$ \\
\hline Solve & $\begin{array}{l}\text { This command tells OASIS to solve and to take into account constraints, target, or minimax } \\
\text { commands first. }\end{array}$ \\
\hline Cancel & Tells the program to cancel the results of a previously solved priority level. \\
\hline Run module & This command allows OASIS to run in parallel with another model. \\
\hline
\end{tabular}

Source: HydroLogics OCL 2009

The OCL commands Target and Constraint are similar in their base definition however have identifiable differences. The Target command can model an operating goal, operating constraint, or a hybrid of the two and can have multiple conditions while the Constraint command can only model constraints and have no more than one condition. The user manual also states that the Constraint command is more straightforward because it can move terms to whichever side of the expression seems more fitting while the Target command must keep all the decision variables on the left-hand side (HydroLogics OCL 2009).

The flexibility found within the program is in the OCL, providing users the ability to write new rules by designing the form of the rule and the parameter values associated with it. This is in combination with the pre-specified rules within the model. Standardized features were designed specifically for modeling the operations of a water resources system, resulting in less user creation of accepted practices. This is also considered a time and money saving feature. The standardized features within OASIS are meant to help with more common modeling needs. It can calculate and handle flow capacities, minimum flow targets, and computing evaporation from a 
reservoir, to name a few. Inputs to OASIS is completely user defined in input files. These files can be in the following format: MS Access, ASCII (plain text), and HEC-DSS (OASIS 2019).

OASIS is marketed and used as a water resources planning tool that is a powerful tool to be used by water managers and other stakeholders. The applications of this program is computeraided negotiating and drought exercises, which enables stakeholders and water managers to see how the system reacts to different demands, changes in operational rules, or even the sequencing of facilities (HydroLogics OASIS 2019).

\subsubsection{Aquarius}

Aquarius is a water allocation software that is driven by an economic efficiency operational criterion that requires the reallocating of stream flows until the net marginal return in all water uses is equal again. It is product out of AQUATIC Informatics, a software company that "addresses critical water data management, analytics, and compliance challenges for the rapidly growing water industry." This software is an analysis framework instead of a single model dedicated to just water allocation. Aquarius supports and can model storage reservoirs, hydropower plants, agricultural water use, municipal and industrial water use, instream recreation water use, reservoir recreation water use, fish habitat protection, and flood control area (Libes 2019).

The reasoning for an economic efficiency criterion to determine water allocation is because of the key role economic demands play in these allocation decisions. There is also a larger accessibility of economic value estimates for more of the nontraditional water uses such as lake and instream recreation, making it much easier to account for and use. The traditional and nontraditional use, if possible, is represented by demand curves which can be either exponential, constant, or linear price functions. Should there be a predetermined level of allocation but no defined economic demand function, then the user can do one of two things. First the user can constrain the model to meet a specified allocation, or second, the user can experiment with replacement demand curves until the water allocation level needed is met (Diaz et al. 2019).

Input into the model is divided into two sections: physical and economic data. The physical data includes what is associated with the operations and dimensions of various system components. This can include power plant efficiency, percent of return from an off stream 
demand area, or maximum reservoir capacity. The economic data is mostly the demand functions from the different water uses competing for the same water (Diaz et al. 2019).

\subsubsection{Modsim-DSS}

Developed at Colorado State University, MODSIM is defined as a network flow model and a river basin decision support system. The goal of this modeling software was to design a program to help the increasing demands that are placed on river basin managers. It has a graphical user interface which is meant to allow for any kind of river basin topography to be modeled. Results of running the model are displayed in graphical plots. It is meant for basin wide or regionally and in regards to long-term operational planning, short-term water management, conflict resolution, and water rights analysis (Colorado 2017, USGS 2019A).

Similar to other water allocation models, it is noted by the designers of the program that there are many stakeholders in publicly owned waters with complex regulations to maintain the environmental and ecological integrity of the water system. The differences among stakeholders and their intentions can make it difficult to effectively plan inputs and outputs into the water system, but Modsim-DSS was designed for "highly complex and constantly evolving river basin management" (Colorado 2017).

\subsection{Case Studies and Applications}

This section considers studies that utilize each of the five models explained in the previous sections.

\subsubsection{RiverWare}

The applications of RiverWare are vast, as can be shown in the following examples. Uses range from flooding control and guarding aquatic life to planning for changes in operational policies and management of water systems in more dry and drought susceptible areas.

A study using RiverWare in combination with an agent-based model (ABM) addressed how artificial systems interacted with natural systems, also called coupled natural-human system (CNHS), in regards to the San Juan river basin located in New Mexico. The framework proposed within the study was meant to be a generalized methodology for water resources management and had a goal to quantify human decisions. The ABM framework adopts a theory of planned 
behavior to characterize human decision-making processes. Input data for this model were historical tributary flows, evapotranspiration rates for each irrigation ditch restricted to the crop water requirement, historic water diversion for NIIP and the San Juan-Chama Project, and operational rules. The stakeholders in this study were farmers. The model was operated on a daily time step from October 1, 1928 to September 30, 2013 (Hyun et al. 2019).

The conclusion of the San Juan River Basin study showed that human activities and streamflow changes can be captured while also computing the risk perception through the usage of the specific risk perception parameters. A more comprehensive look at the entire river basin would also need to include more agents such as power plants, cities, municipalities, and reservoirs, not just farmers as this is not an inclusive representation of the stakeholders for this river basin (Hyun et al. 2019).

In the Urumqi river basin located in Xinjiang, China, a drought scenario analysis was completed with RiverWare due to progressively severe periods of drought coupled with an increasing demand of the water source. Snow melt was the main source of water and the study location was situated in a dry west mountainous watershed. Two drought scenarios were developed: reduced precipitation and increased temperatures. In addition, historical data were used to verify that that model accurately embodied the river basin and its functions (Abudu et al. 2018).

The methodology of this study was to start with a conceptual node-link model to illustrate the connections between canals, rivers, laterals, drains, and diversion points. This was this put into RiverWare with links made between surface and groundwater. This link was done specifically for their increased pumping of groundwater and the serious implications it can have on the balance of the water system. This may only be necessary in arid areas. The data for groundwater was taken from previous works and additional parameters were determined from GIS and on-site measurements (Abudu et al. 2018).

The study concluded that RiverWare was able to capture the intricate hydrological processes in the Xinjiang river basin with the use of groundwater objects, seepage losses from the river and canals, groundwater pumping, and return flows. RiverWare was deemed suitable for the complexity of agricultural land located within the basin. The success of the model will be used in future decision making on the operational policies and management practices of the river basin in general and in times of severe drought (Abudu et al. 2018). 
In the Yakima River located in the Pacific Northwest of the United States, a study was done to show that in widely managed watershed there are challenges in defining the role and influences that different management practices have on watershed hydrology. The use of RiverWare in coincidence with the Soil and Water Assessment Tool (SWAT) was investigated. Results displayed RiverWare doing a better job at simulating stream flow using its reservoir optimization scheme as compared to SWAT's default operation scheme. Overall the findings of this study showed that the combined use of SWAT with RiverWare improved the streamflow simulations by a measurable amount. What this study represents is another case study displaying the merits of RiverWare by itself but also coupled with other software's. It enhances SWAT in this instance while also proving that management practices are important and necessary in hydrological modeling (Qiu et al. 2019).

Additional river basins have been studied using RiverWare (Table 7). In its simplified state it references the many applications that the software RiverWare can have on river basins. As seen in the case studies in this section, RiverWare enables users to model and plan for their respective system for a multitude of scenarios and with different variables (RiverWare 2015).

\section{Table 7. RiverWare case study applications}

\begin{tabular}{|l|l|}
\hline River Basin & RiverWare Applications \\
\hline Tennessee Valley & $\begin{array}{l}\text { Flooding control, protecting aquatic life, maintaining water levels for recreational use, and } \\
\text { creating economical hydropower production schedules. }\end{array}$ \\
\hline Colorado River & $\begin{array}{l}\text { Basin policy negotiations, setting monthly target operations for the entire basin, and future } \\
\text { salinity mitigations that may be needed. }\end{array}$ \\
\hline San Juan & $\begin{array}{l}\text { Control flooding, target storages, improve habitats for endangered species, and to meet } \\
\text { water supply demands. }\end{array}$ \\
\hline Upper Rio Grande & $\begin{array}{l}\text { International treaty obligations, Indian water rights, private rights and contracts, and trans } \\
\text { basin water diversion. }\end{array}$ \\
\hline
\end{tabular}

Source: RiverWare 2015

\subsubsection{StateMod}

In the case studies for StateMod, modeling includes increasing demand of water use and how to handle this influx and to determine the amount of water available the current water use 
levels, operating policies, and existed water availability is considered (AECOM \& BOYLE 2012),

This first study gives an unparalleled look at the state of Colorado's water resources for planning, all based on information on past droughts, wet spells, and any potential changes in climate conditions in combination of models developed by the Colorado Water Conservation Board (CWCB) and the Division of Water Resources. The study area entails the major tributary river basins of the Colorado River within the state of Colorado: Yampa and White, Upper Colorado, Gunnison, and San Juan/Dolores. The need for such a study comes from increasing demands for both traditional and nontraditional uses of its water supply coupled with population growth; oil, gas, and mineral development; recent drought, and potential climate change (AECOM \& BOYLE 2012).

Phase I was specifically an assessment of water availability based on current existing levels of water use and understandings of current operational rules for water storage and diversion. The results of Phase I will help to support the continual assessment of flood protection and management, instream flow protection, water conservation, endangered species recovery, streamflow storage, and reservoir storage to support water supply (AECOM \& BOYLE 2012).

The study compared three different conditions for water supply: historical hydrology, extended historical hydrology, and climate-adjusted hydrology, shown in Table 8. Based on these conditions, information for water users and providers were as follows: access to model results at explicit locations; the ability to make decisions on what hydrologic dataset to use for planning purposes; ability to perform statistical analysis based on selected hydrology and locations.. Each of these three scenarios allows the Colorado River water managers, stakeholders, and policy makers to make decisions with an extensive range of scenarios. Table 9 shows the findings of the water availability assessment, looking specifically at the years 2040 and 2070. The projections for both years are for temperature, precipitation, crop irrigation requirements, natural flow, modeled streamflow, water availability, reservoir storage, and consumptive use (AECOM \& BOYLE 2012). 
Table 8. Phase I of Colorado River Water availability study water availability assessment

\begin{tabular}{|l|l|l|}
\hline & Data and Tools & Results \\
\hline Historical Data & $\begin{array}{l}\text { Colorado Decision } \\
\text { Support System (CDSS) }\end{array}$ & $\begin{array}{l}\text { Historical natural flows, modeled stream flows, } \\
\text { consumptive use, reservoir levels, and water availability. }\end{array}$ \\
\hline $\begin{array}{l}\text { Extended Historical } \\
\text { Hydrology }\end{array}$ & Extending paleo datasets & Extended natural flows and wet/dry spell statistics. \\
\hline $\begin{array}{l}\text { Climate-Adjusted } \\
\text { Hydrology }\end{array}$ & $\begin{array}{l}\text { Variable infiltration } \\
\text { capacity (VIC) model }\end{array}$ & $\begin{array}{l}\text { Climate-adjusted temperature, precipitation, and natural } \\
\text { flows. }\end{array}$ \\
\hline
\end{tabular}

Source: AECOM \& BOYLE 2012

Table 9. Phase I of Colorado River Water availability study findings based on 2040 and 2070 projections

\begin{tabular}{|c|c|c|}
\hline & 2040 & 2070 \\
\hline Temperature & Increases range from $1.8^{\circ} \mathrm{F}$ to $5.2^{\circ} \mathrm{F}$ & Increases range from $4.8^{\circ} \mathrm{F}$ to $8.1^{\circ} \mathrm{F}$ \\
\hline Precipitation & $\begin{array}{l}\text { Winter average changes by } 102 \% \text { to } \\
116 \% \text { of historical }\end{array}$ & $\begin{array}{l}\text { Winter average changes by } 99 \% \text { to } 127 \% \\
\text { of historical }\end{array}$ \\
\hline $\begin{array}{l}\text { CIR (Crop Irrigation } \\
\text { Requirements) }\end{array}$ & $\begin{array}{l}\text { Average annual CIR increases by } 1.9 \text { to } \\
7.4 \text { inches }\end{array}$ & $\begin{array}{l}\text { Average annual CIR increases by } 5.1 \text { to } \\
10.9 \text { inches }\end{array}$ \\
\hline Natural Flow & $\begin{array}{l}\text { Runoff shifts earlier by an average of } 8 \\
\text { days. }\end{array}$ & $\begin{array}{l}\text { Runoff shifts earlier by an average of } 14 \\
\text { days }\end{array}$ \\
\hline Modeled Streamflow & $\begin{array}{l}\text { Historical annual low-flow values } \\
\text { generally fall within the range of } \\
\text { projected low-flow values }\end{array}$ & $\begin{array}{l}\text { Some } 2070 \text { projections show greater } \\
\text { average annual modeled streamflow } \\
\text { compared to } 2040 \text { projections }\end{array}$ \\
\hline $\begin{array}{l}\text { Water Available to } \\
\text { Meet Future Demands }\end{array}$ & $\begin{array}{l}\text { Values generally fall within the range of } \\
\text { projected minimum water availability } \\
\text { values for } 2040 \text { throughout the Study } \\
\text { Area }\end{array}$ & $\begin{array}{l}\text { Values generally fall within the range of } \\
\text { projected minimum water availability } \\
\text { values for } 2070 \text { in the northern and central } \\
\text { portion of the Study Area }\end{array}$ \\
\hline $\begin{array}{l}\text { Modeled Reservoir } \\
\text { Storage }\end{array}$ & $\begin{array}{l}\text { Reservoirs are generally drawn down to } \\
\text { lower levels, and generally fill to } \\
\text { historical levels }\end{array}$ & $\begin{array}{l}\text { Reservoirs are generally drawn down to } \\
\text { lower levels, and do not fill to historical } \\
\text { levels, except in the northern portion of the } \\
\text { Study Area }\end{array}$ \\
\hline $\begin{array}{l}\text { Modeled Consumptive } \\
\text { Use }\end{array}$ & $\begin{array}{l}\text { Projected consumptive use increases in } \\
\text { most months in every basin except the } \\
\text { San Juan. Projected consumptive use in } \\
\text { the San Juan generally increases in } \\
\text { spring months only }\end{array}$ & $\begin{array}{l}\text { Projected consumptive use for the } 2070 \\
\text { projections is higher than for the } 2040 \\
\text { projections in every basin except the San } \\
\text { Juan. }\end{array}$ \\
\hline
\end{tabular}

Source: AECOM \& BOYLE 2012 
The results of this study provided information on how much water is available within the Colorado River basin to provide future water needs, both consumptive and non-consumptive. It based these on current levels of water usage, current operating and management processes, and existing water supply systems. Future studies would need to look at future demands and different management and operational agreements and styles in order to get a more comprehensive model of the river basin (AECOM \& BOYLE 2012).

\subsubsection{SWAM}

The main objective for the SWAM case studies was to look at operational rules and the management of supply plans in conjunction with current water availability to see the changes these current conditions would make with future withdrawals while maintaining a designated minimum flow (Smith 2017A; Smith 2017B).

This study looks at the Edisto River basin located in South Carolina, specifically the impacts to the river flows from human interventions and impacts: discharges, withdrawals, impoundment, and interbasin transfers. Model inputs, shown in Table 10, were based on the different tributaries and water users. The goals of the model were to evaluate surface water availability, develop regional water supply plans, predict future availability and demands, test effectiveness of new operating rules or management strategies, and to evaluate the impacts that future withdrawals will have and the minimum flows needed. Two model versions were completed: one baseline model and one calibration model. The baseline model represented current future demands and operations. The calibration version was developed for historical conditions. The calibration of this model was a model verification since the primary inputs were not changed. The data used for the historical period was from 1983 to 2013, selected for its high confidence reported in both withdrawal and discharge data. This 31-year period also gives adequate high and low flow periods (Smith 2017A). 
Table 10. Model Inputs for the Edisto River Basin

\begin{tabular}{|c|c|c|}
\hline & Model Inputs Name & Model Inputs Description \\
\hline \multirow{3}{*}{ Model Tributaries } & Headwater Flows & Unimpaired flows at the top of a given reach being modeled. \\
\hline & Confluence Flows & Estimated from reference UIFs \\
\hline & Reach Gains and Losses & $\begin{array}{l}\text { Capture ungauged flow gains and losses associated with } \\
\text { increasing drainage area with distance downstream or with } \\
\text { interaction with leakage or seepage. }\end{array}$ \\
\hline \multirow{4}{*}{ Water Users } & Sources of Supply & Withdrawn tributaries, diversion locations, and permit limits. \\
\hline & Demands & $\begin{array}{l}\text { Municipal, industrial, thermopower, golf course, and } \\
\text { agricultural water users. }\end{array}$ \\
\hline & Interbasin Imports & Water users who access and/or discharge into multiple basins. \\
\hline & $\begin{array}{l}\text { Consumptive Use and } \\
\text { Return Flows }\end{array}$ & $\begin{array}{l}\text { Return flows are discharges and consumptive use is the use } \\
\text { from all sources of demand, calculated from reported } \\
\text { withdrawals and discharges. }\end{array}$ \\
\hline
\end{tabular}

Source: Smith 2017A

The results of this study showed a strong agreement between the measured data and the model for all the target sites. Any discrepancies were within the reported range of uncertainty associated with USGS flow data (Smith 2017A).

The next study is for the Saluda River Basin, done primarily for policy planning, future permitting, and overall planning efforts throughout the basin. For this model the inputs, shown in Table 11, were based on model tributaries, reservoirs, and water users. The model looks at hydrological data from 1925 through 2013 with the river and its main tributaries and how human impacts (withdrawals, discharges, impoundment, and interbasin transfers) change the river flow. Similar to the Edisto River basin model, two model versions were created: baseline and calibration. The main objectives of this modeling study were as to do the following: create regional water-supply plans; test the effectiveness of new operational rules and management strategies; investigate impacts of future needs and subsequent withdrawals; with the support of the Surface Water Withdrawal, Permitting, Use, and Reporting Act evaluate the availability of surface water. All of these objectives were meant to be available for all trained individuals in the DNR and DHEC as well stakeholders within the Saluda River Basin (Smith 2017B). 
Table 11. Model Inputs for the Saluda River Basin Model

\begin{tabular}{|c|c|c|}
\hline \multirow{3}{*}{ Model Tributaries } & Headwater Flows & Unimpaired flows at the top of a given reach being modeled. \\
\hline & Confluence Flows & Estimated from reference UIFs \\
\hline & $\begin{array}{l}\text { Reach Gains and } \\
\text { Losses }\end{array}$ & $\begin{array}{l}\text { Capture ungauged flow gains and losses associated with increasing } \\
\text { drainage area with distance downstream or with interaction with } \\
\text { leakage or seepage. }\end{array}$ \\
\hline \multirow{4}{*}{ Reservoirs } & Evaporation & $\begin{array}{l}\text { Measured using Hargreaves method with daily temperature data } \\
\text { and latitude. }\end{array}$ \\
\hline & Direct Precipitation & $\begin{array}{l}\text { Direct precipitation to the surfaces of Lake Murray and Lake } \\
\text { Greenwood. }\end{array}$ \\
\hline & $\begin{array}{l}\text { Area-Capacity } \\
\text { Relationships and } \\
\text { Flood Control Outflow }\end{array}$ & Done for 6 reservoirs within the river basin. \\
\hline & $\begin{array}{l}\text { Releases and Operating } \\
\text { Rules }\end{array}$ & $\begin{array}{l}\text { Based on dam and outflow locations information and is modeled } \\
\text { based on prescribed operating rules and release targets. }\end{array}$ \\
\hline \multirow[b]{4}{*}{ Water Users } & Sources of Supply & Withdrawn tributaries, diversion locations, and permit limits. \\
\hline & Demands & $\begin{array}{l}\text { Municipal, industrial, thermopower, golf course, and agricultural } \\
\text { water users. }\end{array}$ \\
\hline & Trans basin Imports & Water users who access and/or discharge into multiple basins. \\
\hline & $\begin{array}{l}\text { Consumptive Use and } \\
\text { Return Flows }\end{array}$ & $\begin{array}{l}\text { Return flows are discharges and consumptive use is the use from } \\
\text { all sources of demand, calculated from reported withdrawals and } \\
\text { discharges. }\end{array}$ \\
\hline
\end{tabular}

Source: Smith 2017B

The conclusion of this study now allows for stakeholders who are trained to access the model through a cloud-based server. The difference scenarios that stakeholders can use are: comparison of unmanaged flow to managed flow and the resulting water availability; changes to withdrawal and discharge permits; different management strategies for the planning of basin activities; comparing current usage patterns to fully permitted use of the allocated water as well as considering the potential for future demand levels. The results of this study will help in multiple planning purposes for the Saluda River Basin and its water users (Smith 2017B). 


\subsubsection{OASIS}

OASIS is a tool utilized for its stakeholder planning and conflict resolution in this case study. One OASIS modeled project was done to help NOAA bridge the gap of forecast and early warning products and the adoption and implementation of water supply utility planning in the Chesapeake Bay region, ranging from 1930-2014. The primary goal of the study was to help inform stakeholders with planning and to create a drought planning tool (DPT) for the Susquehanna River Basin Commission (SRBC) (Weiss et al. 2019).

The DPT consists of time series climatology and meteorological drought indices and forecasts, model code for water supply drought operations, and a post-processing dashboard for elevation of tradeoffs among cost, water supply reliability, and other performance measures for drought scenarios. The SRBC used OASIS to develop and test different management practices for the Conowingo Pond, relating to hydroelectric, water supply recreation, and environmental objectives. Time series values from 1930-2014 were generated from the OASIS model input time series and converted to a volume for each day of the time series (Weiss et al. 2019).

Two different simulations were completed, one for the comparison of drought indices and reforecasts to dry periods and more severe droughts within the simulated historical timeframe under the current water supply operations, and two being to compare different operating strategies. Findings showed that drought indices are more relevant for the operation of reservoir supply than run-of-river systems. It was also demonstrated that current operating rules in lowflow periods are typically tuned to demand levels. Demand changes result in alternative drought indicators needed to be used with the correct lead times to protect system reliability through the drought periods. One other notable result in this study was that with a slight decrease in reliability of reservoir storage, there was a reduction in operating costs. The combined effort of forecast and storage-based triggers were the driving force of this by the reduction of the amount of pumping required to refill the secondary reservoirs (Weiss et al. 2019).

\subsubsection{Aquarius}

A study done in the Waccamaw Watershed Academy was done at Coastal Carolina University. Aquarius was used to monitor a pair of continuous water quality sensors, deployed at different depths, which in turn allows for the comparison of water quality readings and help to determine vertical stratification in the water column at the site (Libes 2019). 
The biggest benefit noted with the use of the Aquarius software was its ability to handle a large quantity of data. Before the use of this program, Excel had been used and was not sufficient for handling or making decision on what to do with the data. Those handling the data had to make significant decisions on what even to graph due to excel not having the decision-making capabilities. However, the transition from Excel to Aquarius empowered the group to do more extensive data exploration. Changing from seasonal to daily to hourly time scale can happen very quickly, the quick creation of publication-quality charts, and data manipulation in real time were all benefits to this study (Libes 2019).

\subsection{Model Comparison}

In this section the models discussed in the previous sections will be compared based on their inputs, outputs, uses, and overall functionality (table 12). Each of the five models on their base level have most of the same features: reservoir storage, stream and river flow, stream gage, aquifer, water user, and operational rules. For less complex modeling it could be assumed that any one of these models could do a reasonable job. However, beyond just the basic features, each model has more advanced features to use to suit the needs of the river basin(s) you need.

The five models compared (table 12) are shown to have different capabilities. Through discussion of case studies for these five models it is also evident that each software addressed different needs. There are four scenarios to be considered for how effective each model would be for West Virginia: drought, population, industry, and operation/management (table 13). These four scenarios will look at how changes in water use from population increases as well in industry usage, the prevalence of drought conditions, and new operational rules and management of the system will effect it. RiverWare and SWAM are considered suitable for all of these scenarios while StateMod, OASIS, and Aquarius are suitable for all but the industry scenario. This is in part due to the fact that these tools do not have the power plant diversion, an important industry user that will need to be accounted for. It can also be reasonably shown that the remaining three tools do not reflect the same amount of features as RiverWare and SWAM. 
Table 12. Model Comparison of Features

\begin{tabular}{|c|c|c|c|c|c|}
\hline Features* & RiverWare & StateMod & SWAM & OASIS & Aquarius \\
\hline Storage Reservoir & $\checkmark$ & $\checkmark$ & $\checkmark$ & $\checkmark$ & $\checkmark$ \\
\hline Pumped Storage & $\checkmark$ & $\mathrm{X}$ & $\mathrm{X}$ & $\mathrm{X}$ & $\mathrm{X}$ \\
\hline River Reach & $\checkmark$ & $\checkmark$ & $\checkmark$ & $\checkmark$ & $\checkmark$ \\
\hline Aggregate Reach & $\checkmark$ & $\mathrm{X}$ & $X$ & $\mathrm{X}$ & $\mathrm{X}$ \\
\hline Flow Junction & $\checkmark$ & $\mathrm{X}$ & $\checkmark$ & $\mathrm{X}$ & $\mathrm{X}$ \\
\hline Control Point & $\checkmark$ & $\checkmark$ & $\checkmark$ & $\checkmark$ & $\checkmark$ \\
\hline Inline Power & $\checkmark$ & $X$ & $\checkmark$ & $\mathrm{X}$ & $\mathrm{X}$ \\
\hline Canal & $\checkmark$ & $\checkmark$ & $\checkmark$ & $\mathrm{X}$ & $\mathrm{X}$ \\
\hline Pipeline & $\checkmark$ & $\checkmark$ & $\checkmark$ & $\mathrm{X}$ & $\mathrm{X}$ \\
\hline Pipe junction & $\checkmark$ & $\checkmark$ & $\checkmark$ & $\mathrm{X}$ & $\mathrm{X}$ \\
\hline Inline Pumping & $\checkmark$ & $\mathrm{X}$ & $\mathrm{X}$ & $\mathrm{X}$ & $\mathrm{X}$ \\
\hline Aggregate Distribution Canal & $\checkmark$ & $\mathrm{X}$ & $\mathrm{X}$ & $\mathrm{X}$ & $\mathrm{X}$ \\
\hline Diversion & $\checkmark$ & $\checkmark$ & $\checkmark$ & $\checkmark$ & $\checkmark$ \\
\hline Water User & $\checkmark$ & $\checkmark$ & $\checkmark$ & $\checkmark$ & $\checkmark$ \\
\hline Groundwater Storage & $\checkmark$ & $\mathrm{X}$ & $\checkmark$ & $\checkmark$ & $\mathrm{X}$ \\
\hline Aquifer & $\checkmark$ & $\checkmark$ & $\checkmark$ & $\mathrm{X}$ & $\checkmark$ \\
\hline Stream Gage & $\checkmark$ & $\checkmark$ & $\checkmark$ & $\checkmark$ & $\checkmark$ \\
\hline Power Plant Diversion & $\checkmark$ & $\mathrm{X}$ & $\checkmark$ & $\mathrm{X}$ & $\mathrm{X}$ \\
\hline Thermal Object/Hydropower & $\checkmark$ & $\checkmark$ & $\checkmark$ & $\checkmark$ & $\mathrm{X}$ \\
\hline Data Object & $\checkmark$ & $\checkmark$ & $\checkmark$ & $\checkmark$ & $\checkmark$ \\
\hline Operational Rule & $\checkmark$ & $\checkmark$ & $\checkmark$ & $\checkmark$ & $\checkmark$ \\
\hline Daily or Monthly Timestep & $\checkmark$ & $\checkmark$ & $\checkmark$ & $\checkmark$ & $\checkmark$ \\
\hline
\end{tabular}

Note: $\checkmark=$ feature exists in the model; feature is not available

* definitions of features are in the Appendix

Source: RiverWare 2015, Colorado DNR 2019, South Carolina DNR 2019, HydroLogics OCL 2009, Libes 2019 
Table 13. Model Comparison of Scenarios

\begin{tabular}{|l|c|c|c|c|}
\hline & Drought & Population & Industry & Operational/Management \\
\hline RiverWare & $\checkmark$ & $\checkmark$ & $\checkmark$ & $\checkmark$ \\
\hline StateMod & $\checkmark$ & $\checkmark$ & X & $\checkmark$ \\
\hline SWAM & $\checkmark$ & $\checkmark$ & $\checkmark$ & $\checkmark$ \\
\hline OASIS & $\checkmark$ & $\checkmark$ & X & $\checkmark$ \\
\hline Aquarius & $\checkmark$ & $\checkmark$ & X & $\checkmark$ \\
\hline
\end{tabular}




\section{Chapter 3. Model Selection and Application for West Virginia}

Chapter 3 will discuss the model selected for West Virginia and the reasoning behind the decision as well as how the model can be applied to the state given information readily available.

\subsection{Model Selection}

Through analysis of all five models the one selected for the modeling of river basins within the state of West Virginia is RiverWare. This selection was made based on case studies, basic and advanced features of the models, and overall ease of use of the program. RiverWare fit this bill best for the state of West Virginia in a few ways.

Referencing back to section 2.2.1 of this paper, the case studies selected for RiverWare were discussed. What stood out in particular was the one in the Urumqi River basin located in China. What first struck as a good fit was the general topography of the river basin and its similarity to the West Virginia. Being mountainous, both locations deal with flooding and snow melt in the springtime. The capabilities of RiverWare are shown to be successful in accurately modeling this through its baseline model with historical data usage when compared to the two drought scenarios selected: reduced precipitation and increased temperature. It should be noted that while West Virginia is located in an area that is not prone to droughts like the western part of the United States, the state is experiencing changing precipitation patterns and increased temperatures leading to dry soil in the summer and fall. With more dry periods or even droughts increasing in the future, RiverWare will be able to model accordingly (US EPA 2016). West Virginia has also seen flood-related disaster declarations nearly every year. Since 1958 the eastern United States has seen a $25 \%$ increase in extremely heavy storms with expectations of average annual precipitation and heavy rainfalls to increase in the coming years. These changes due to climate change are cause for adjusting or creating new management styles of the water system in the West Virginia river basins so the state is more apt to deal with an influx or decrease of available water (US EPA 2016).

The water users in the state are also diverse. There is a growing population in some urban areas while in large portions of that state there is a decreasing population. Between 2010 and 2018 there was a $2.6 \%$ decrease in population with 27,000 more people leaving the state than moving in. By percent, the top five counties with the largest loss of population between 2010 and 
2018 were all located in the southern coalfields. Overall, rural West Virginia is losing its population at a greater rate than its urban counterpart with a $-4.6 \%$ rural county population growth. The eastern panhandle tip consisting of Morgan, Berkeley, and Jefferson counties have all see population growth from D.C. suburbs expanding at $1.4 \%, 12.4 \%$, and $6.20 \%$ respectively. The unique benefit this brings is the ability for water to be pulled from areas with lesser demands (i.e. where population is declining) to areas where population and water demand is increasing. RiverWare has the ability to do interbasin transfers and a variety of water users, giving this unique situation a potential solution in modeling and potential real-world application (O'Leary 2019).

\subsection{Application of RiverWare to West Virginia}

For the purpose of this paper, the application of RiverWare to West Virginia will be considered by evaluating the Tygart Valley watershed with an analysis of data sources currently available and where there is a lack of data available that will be necessary for an encompassing model. Data sources are considered for a future model that will evaluate changing water stresses in the watershed.

Tygart Valley River watershed is roughly 1,373 square miles (879,656 acres) located in Pocahontas, Randolph, Webster, Upshur, Lewis, Barbour, Tucker, Taylor, Preston, Marion, and Monongalia counties. The river starts in Pocahontas County and generally flows north with the Middle Fork and Buckhannon rivers being the two largest tributaries of the Tygart Valley River. The land uses in the watershed vary and include the following: strip mines and quarries, reservoirs, streams and canals, industrial/commercial services, residential/mixed urban, shrub and brush rangeland, cropland and pasture, non-forested wetlands, forested wetlands, mixed forest land, evergreen forest land, and deciduous forest land (Bailey and Wirts 2003).

Land use is varied throughout the watershed. Recreationally there is access to hunting, fishing, hiking, camping, and picnicking. The state parks located within the watershed include Tygart Lake State Park, Audra State Park, and Valley Falls State Park along with national forest land and Kumbrabow State Forest. There is also a decent mix of industrial use including coal mining, timber harvesting, agriculture, oil and gas, and quarrying (Bailey and Wirts 2003).

The data that would be needed for a model of the Tygart Valley River Watershed would include large quantity water users and their water demand, reservoirs, stream flow, operational 
rule(s), canals, and groundwater storage and pumping. Some of this information is readily available for download and is represented in Tables 13 and 14. There are also 11 public water supply users within the watershed. Water use ranges between 62,000,000 and 2,259,195,900 gallons. Operational rules and management of the watershed can be found in the Drought Contingency Plan for Tygart Lake West Virginia as well as the Engineering and Design Water Control Management. Large quantity users in the Tygart Valley watershed (table 14) is shown with their purpose of use, the percentage of source over a three year average, and three year annual average in gallons. The large quantity users in table 14 is from November of 2013, so more recent information as it becomes available will be needed. USGS also provides information on a state and county level in five-year increments from 1985 to 2015 for the following categories: total population, public supply, domestic, commercial, industrial, mining, livestock, aquaculture, irrigation, wastewater treatment, and power suppliers. These various stakeholders in the West Virginia water system can potentially come to the table to discuss water usages and see results of different levels of usage and management practices. Similar to some current RiverWare models being implemented for different river basins, this will help with any potential negotiating that needs done (USACE 2016; USACE 1992; WV DEP 2013). 
Table 14. Large quantity users in Tygart Valley watershed

\begin{tabular}{|c|c|c|c|c|c|}
\hline $\begin{array}{l}\text { Facility } \\
\text { ID }\end{array}$ & Facility Name & Use Category & \multicolumn{2}{|c|}{ Source and \% of 3 Year Average } & 3 Year Annual \\
\hline 3460 & Aggregate Quarry & Mining & $\begin{array}{c}\text { Surface Water } \\
36.25 \%\end{array}$ & $\begin{array}{c}\text { Groundwater } \\
63.75 \%\end{array}$ & $9,052,333$ \\
\hline 1972 & $\begin{array}{l}\text { Belington Water } \\
\text { Treatment Plant }\end{array}$ & Public Water Supply & $\begin{array}{c}\text { Surface Water } \\
100 \%\end{array}$ & & $80,445,667$ \\
\hline 1142 & Beverly Water Plant & Public Water Supply & $\begin{array}{c}\text { Surface Water } \\
100 \%\end{array}$ & & $153,598,604$ \\
\hline 8309 & $\begin{array}{c}\text { Carter Roag Coal - } \\
\text { Star Bridge } \\
\text { Preparation Plant }\end{array}$ & Mining & $\begin{array}{c}\text { Surface Water } \\
100 \%\end{array}$ & & $14,990,300$ \\
\hline 1228 & $\begin{array}{c}\text { City of Buckhannon } \\
\text { Water Plant }\end{array}$ & Public Water Supply & $\begin{array}{c}\text { Surface Water } \\
100 \%\end{array}$ & & $781,452,937$ \\
\hline 1247 & City of Fairmont & Public water supply & $\begin{array}{c}\text { Surface Water } \\
100 \%\end{array}$ & & $2,387,969,191$ \\
\hline 10069 & $\begin{array}{c}\text { Coalton Water } \\
\text { System }\end{array}$ & Public water supply & & $\begin{array}{c}\text { Groundwater } \\
100 \%\end{array}$ & $8,380,200$ \\
\hline 1900 & Elkins Water Works & Public water supply & $\begin{array}{c}\text { Surface Water } \\
100 \%\end{array}$ & & $789,237,288$ \\
\hline 10094 & $\begin{array}{l}\text { Hawthorne Coal } \\
\text { Company - Sawmill } \\
\text { Run Complex }\end{array}$ & Mining & $\begin{array}{c}\text { Surface Water } \\
81.66 \%\end{array}$ & $\begin{array}{c}\text { Groundwater } \\
18.34 \%\end{array}$ & $15,085,867$ \\
\hline 10032 & $\begin{array}{c}\text { Huttonsville } \\
\text { Correctional Center }\end{array}$ & Public water supply & $\begin{array}{c}\text { Surface Water } \\
100 \%\end{array}$ & & $68,086,667$ \\
\hline 7573 & $\begin{array}{l}\text { Monongah Water } \\
\text { Plant }\end{array}$ & Public water supply & $\begin{array}{c}\text { Surface Water } \\
100 \%\end{array}$ & & $271,148,083$ \\
\hline 2223 & $\begin{array}{l}\text { Norton-Harding- } \\
\text { Jimtown Public } \\
\text { Service District }\end{array}$ & Public water supply & & $\begin{array}{c}\text { Groundwater } \\
100 \%\end{array}$ & $85,703,533$ \\
\hline 10001 & $\begin{array}{l}\text { Philippi Municipal } \\
\text { Water }\end{array}$ & Public Water Supply & $\begin{array}{c}\text { Surface Water } \\
100 \%\end{array}$ & & $406,463,000$ \\
\hline 10014 & $\begin{array}{c}\text { Shinnston Water } \\
\text { Board }\end{array}$ & Public Water Supply & $\begin{array}{c}\text { Surface Water } \\
100 \%\end{array}$ & & $400,171,100$ \\
\hline 1856 & Taylor County PSD & Public Water Supply & $\begin{array}{c}\text { Surface Water } \\
100 \% \\
\end{array}$ & & $703,633,667$ \\
\hline 4339 & $\begin{array}{c}\text { Town of Mill Creek } \\
\text { Municipal Water } \\
\text { Plant }\end{array}$ & Public Water Supply & $\begin{array}{c}\text { Surface Water } \\
100 \%\end{array}$ & & $74,262,000$ \\
\hline 10103 & $\begin{array}{l}\text { Wolf Run Mining - } \\
\text { Sentinel Complex }\end{array}$ & Mining & $\begin{array}{c}\text { Surface Water } \\
21.9 \%\end{array}$ & $\begin{array}{c}\text { Groundwater } \\
78.10 \%\end{array}$ & $81,209,500$ \\
\hline
\end{tabular}

Source: WV DEP 2013 


\section{Table 15. Source of Data Available for West Virginia from USGS}

\begin{tabular}{|c|c|c|}
\hline & & $\begin{array}{c}\text { Number of } \\
\text { sites }\end{array}$ \\
\hline \multirow{4}{*}{ Groundwater } & Current Conditions & 18 \\
\hline & $\begin{array}{l}\text { Historical } \\
\text { Observations }\end{array}$ & 19 \\
\hline & Daily Data & 51 \\
\hline & Field Measurements & 5268 \\
\hline \multirow{5}{*}{ Surface Water } & Current Conditions & 201 \\
\hline & $\begin{array}{l}\text { Historical } \\
\text { Observations }\end{array}$ & 218 \\
\hline & Daily Data & 340 \\
\hline & Field Measurements & 835 \\
\hline & Peak-Flow Data & 267 \\
\hline \multirow{5}{*}{ Precipitation } & 1 - hour & \multirow{5}{*}{67} \\
\hline & 6 - hours & \\
\hline & 12 - hours & \\
\hline & 24 - hours & \\
\hline & 7 - days & \\
\hline \multirow{2}{*}{$\begin{array}{l}\text { Lake and } \\
\text { Reservoirs }\end{array}$} & Gain Height (ft.) & 17 \\
\hline & Elevation (ft.) & 4 \\
\hline
\end{tabular}

Source: USGS 2019D

For the Tygart Valley watershed there is data available from USGS for input into a RiverWare model, as shown in Table 14. Streamflow by county looks at Barbour, Greenbrier, Lewis, Marion, Monongalia, Pocahontas, Preston, Raleigh, Randolph, Taylor, Tucker, Upshur, and Webster counties, each county having a different number of sites associated with them based on how much of the county is actually located within the watershed. It should be noted that the 745 sites for streamflow by county is not just stream gages. This includes other sites such as wells. Daily streamflow for major rivers looks at 20 different sites and 18 sites for the monthly streamflow for major rivers. It should be noted that a few of these sites do not have the information readily available on the USGS site but can be found through contacting the local USGS office operating the station. The groundwater levels by county look at the same counties 
stated for streamflow by county, again with the number of sites representative of how much each county is located within the watershed. The remaining four sources of data (incremental evapotranspiration, incremental precipitation, area weighted mean precipitation, and area weighted mean actual evapotranspiration) have a number associated for the watershed as a whole. Table 15 depicts a more in-depth look at the Tygart Valley watershed giving specific site name and numbers respectively.

Table 16. USGS Tygart Valley watershed data availability of daily discharge data

\begin{tabular}{|l|l|}
\hline Data Type & Number of Sites \\
\hline Streamflow by County & 745 \\
\hline Daily Streamflow for Major Rivers & 20 \\
\hline Monthly Streamflow for Major Rivers & 18 \\
\hline Groundwater levels by county & 226 \\
\hline Incremental Evapotranspiration & Watershed Total \\
\hline incremental Precipitation & Watershed Total \\
\hline Area weighted mean precipitation & Watershed Total \\
\hline Area weighted mean actual evapotranspiration & Watershed Total \\
\hline
\end{tabular}

Source: USGS 2019B 
Table 17. USGS Tygart Valley watershed collections sites data

\begin{tabular}{|c|c|c|c|c|c|c|c|}
\hline \multirow[b]{2}{*}{$\begin{array}{l}\text { Site } \\
\text { Number }\end{array}$} & \multirow[b]{2}{*}{ Site Name } & \multicolumn{2}{|c|}{ Gage Height } & \multicolumn{2}{|c|}{ Precipitation } & \multicolumn{2}{|c|}{ Discharge } \\
\hline & & $\begin{array}{c}\text { Begin } \\
\text { Date }\end{array}$ & $\begin{array}{l}\text { End } \\
\text { Date }\end{array}$ & $\begin{array}{c}\text { Begin } \\
\text { Date }\end{array}$ & $\begin{array}{l}\text { End } \\
\text { Date }\end{array}$ & $\begin{array}{c}\text { Begin } \\
\text { Date }\end{array}$ & $\begin{array}{l}\text { End } \\
\text { Date }\end{array}$ \\
\hline 3049925 & $\begin{array}{l}\text { TYGART VALLEY RIVER AT } \\
\text { VALLEY HEAD, WV }\end{array}$ & $\begin{array}{l}2019- \\
09-25\end{array}$ & $\begin{array}{ll}2019- \\
11-21\end{array}$ & $*$ & $*$ & $*$ & $*$ \\
\hline 3049975 & $\begin{array}{l}\text { TYGART VALLEY RIVER AT MILL } \\
\text { CREEK, WV }\end{array}$ & $\begin{array}{l}2019- \\
08-19\end{array}$ & $\begin{array}{l}2019- \\
11-21\end{array}$ & $*$ & $*$ & $*$ & $*$ \\
\hline 3050000 & $\begin{array}{l}\text { TYGART VALLEY RIVER NEAR } \\
\text { DAILEY, WV }\end{array}$ & $\begin{array}{l}2019- \\
07-24\end{array}$ & $\begin{array}{l}2019- \\
11-21\end{array}$ & \begin{tabular}{|c|}
$2014-09-$ \\
06
\end{tabular} & $\begin{array}{l}2019- \\
11-21\end{array}$ & $\begin{array}{l}1996- \\
10-01\end{array}$ & $\begin{array}{l}2019- \\
11-21\end{array}$ \\
\hline 3050350 & $\begin{array}{l}\text { TYGART VALLEY R BELOW INLET } \\
\text { WORKS, ELKINS, WV }\end{array}$ & $\begin{array}{l}2019- \\
07-24\end{array}$ & $\begin{array}{l}2019- \\
11-21\end{array}$ & $*$ & $*$ & $*$ & $*$ \\
\hline 3050450 & $\begin{array}{l}\text { TYGART VALLEY R ABOVE } \\
\text { OUTLET WORKS, ELKINS, WV }\end{array}$ & $\begin{array}{l}2019- \\
07-24\end{array}$ & $\begin{array}{l}2019- \\
11-21\end{array}$ & $*$ & $*$ & $*$ & $*$ \\
\hline 3050460 & $\begin{array}{l}\text { TYGART VALLEY R BELOW } \\
\text { OUTLET WORKS, ELKINS, WV }\end{array}$ & $\begin{array}{l}2019- \\
07-24\end{array}$ & $\begin{array}{l}2019- \\
11-08\end{array}$ & $*$ & $*$ & $*$ & $*$ \\
\hline 3050500 & $\begin{array}{l}\text { TYGART VALLEY RIVER NEAR } \\
\text { ELKINS, WV }\end{array}$ & $\begin{array}{l}2007- \\
10-01\end{array}$ & $\begin{array}{l}2019- \\
11-21\end{array}$ & \begin{tabular}{|c|}
$2014-07-$ \\
09
\end{tabular} & $\begin{array}{l}2019- \\
11-21\end{array}$ & $\begin{array}{l}1996- \\
10-01\end{array}$ & $\begin{array}{l}2004- \\
09-30\end{array}$ \\
\hline 3051000 & $\begin{array}{l}\text { TYGART VALLEY RIVER AT } \\
\text { BELINGTON, WV }\end{array}$ & $\begin{array}{l}2019- \\
07-24\end{array}$ & $\begin{array}{l}2019- \\
11-21\end{array}$ & $\begin{array}{c}2014-10- \\
01\end{array}$ & $\begin{array}{l}2019- \\
11-21\end{array}$ & $\begin{array}{l}1996- \\
10-01\end{array}$ & $\begin{array}{l}2019- \\
11-21\end{array}$ \\
\hline 3054500 & $\begin{array}{l}\text { TYGART VALLEY RIVER AT } \\
\text { PHILIPPI, WV }\end{array}$ & $\begin{array}{l}2019- \\
07-25\end{array}$ & $\begin{array}{l}2019- \\
11-21\end{array}$ & \begin{tabular}{|c|}
$2015-12-$ \\
17
\end{tabular} & $\begin{array}{l}2019- \\
11-21\end{array}$ & $\begin{array}{l}1996- \\
10-01\end{array}$ & $\begin{array}{l}2019- \\
11-21\end{array}$ \\
\hline 3056000 & $\begin{array}{l}\text { TYGART VALLEY R AT TYGART } \\
\text { DAM NR GRAFTON, WV }\end{array}$ & $\begin{array}{l}2007- \\
10-01\end{array}$ & $\begin{array}{l}2019- \\
11-21\end{array}$ & $*$ & $*$ & $\begin{array}{l}2009- \\
10-01\end{array}$ & $\begin{array}{l}2019- \\
11-21\end{array}$ \\
\hline 3057300 & \begin{tabular}{|l} 
TYGART VALLEY RIVER AT \\
COLFAX, WV
\end{tabular} & $\begin{array}{l}2007- \\
10-01\end{array}$ & $\begin{array}{l}2019- \\
11-21\end{array}$ & $*$ & $*$ & $\begin{array}{l}2010- \\
10-01\end{array}$ & $\begin{array}{l}2019- \\
11-21\end{array}$ \\
\hline
\end{tabular}

Source: USGS 2019C

General watershed data are represented in figure 1. Locations of stream gages, dams, wastewater treatment plants, West Virginia cities, and rivers within the Tygart Valley watershed are shown. Collection of data for West Virginia for groundwater, precipitation, and lakes and reservoirs are also available in Table 15 and for the Tygart Valley watershed in Table 14, 16, and 17. The use of all these tables and the data it provides or the capability to find such data will aid in the creation of a watershed model for the Tygart Valley.

Figure 2 represents the Tygart Valley watershed and a potential model and where data would be obtained. It should be noted that this is not an accurate model and should not be used as such. It simply shows where data from the watershed can be used and inputted into the RiverWare model. 


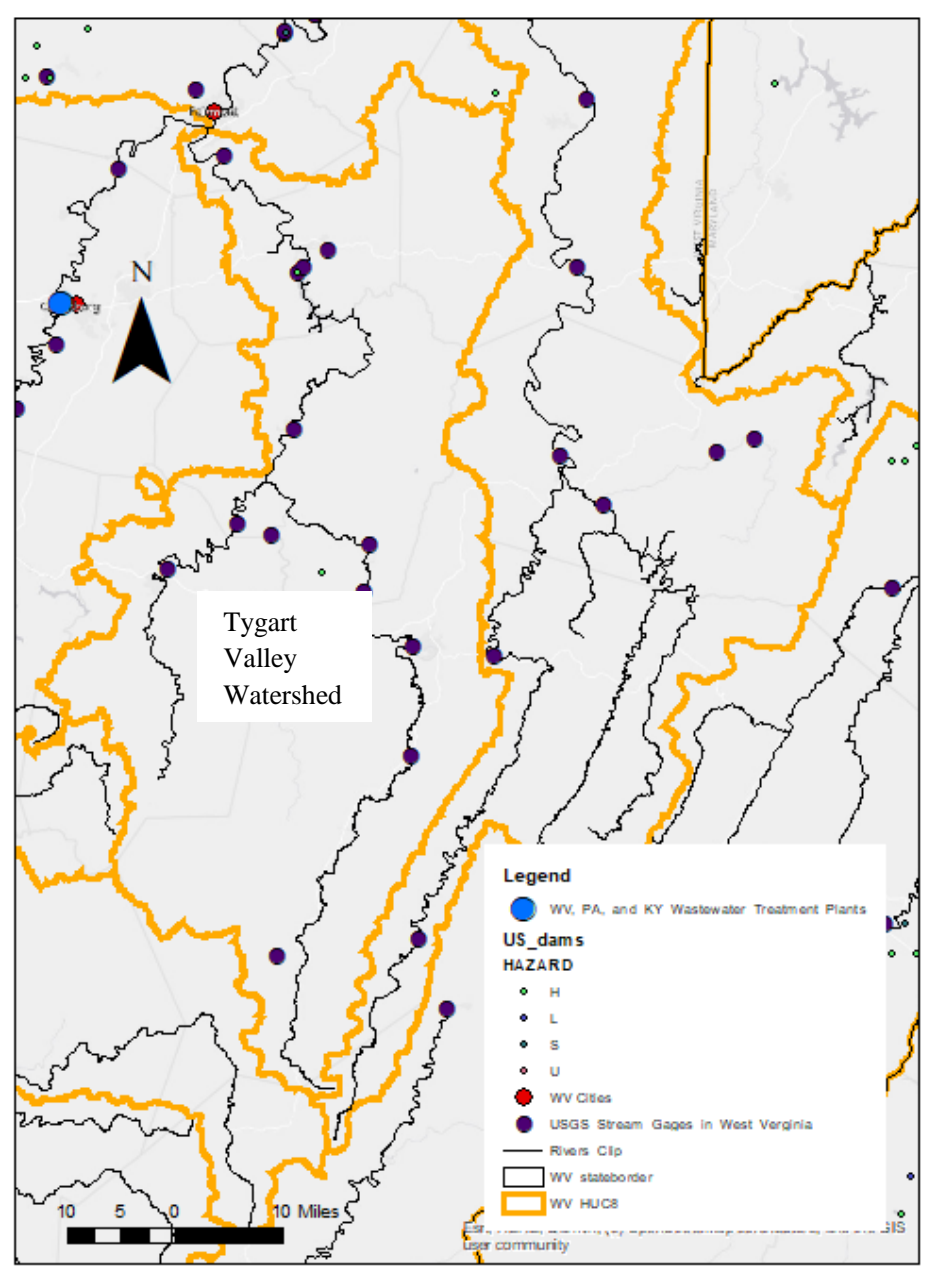

Figure 1. Tygart Valley Watershed 


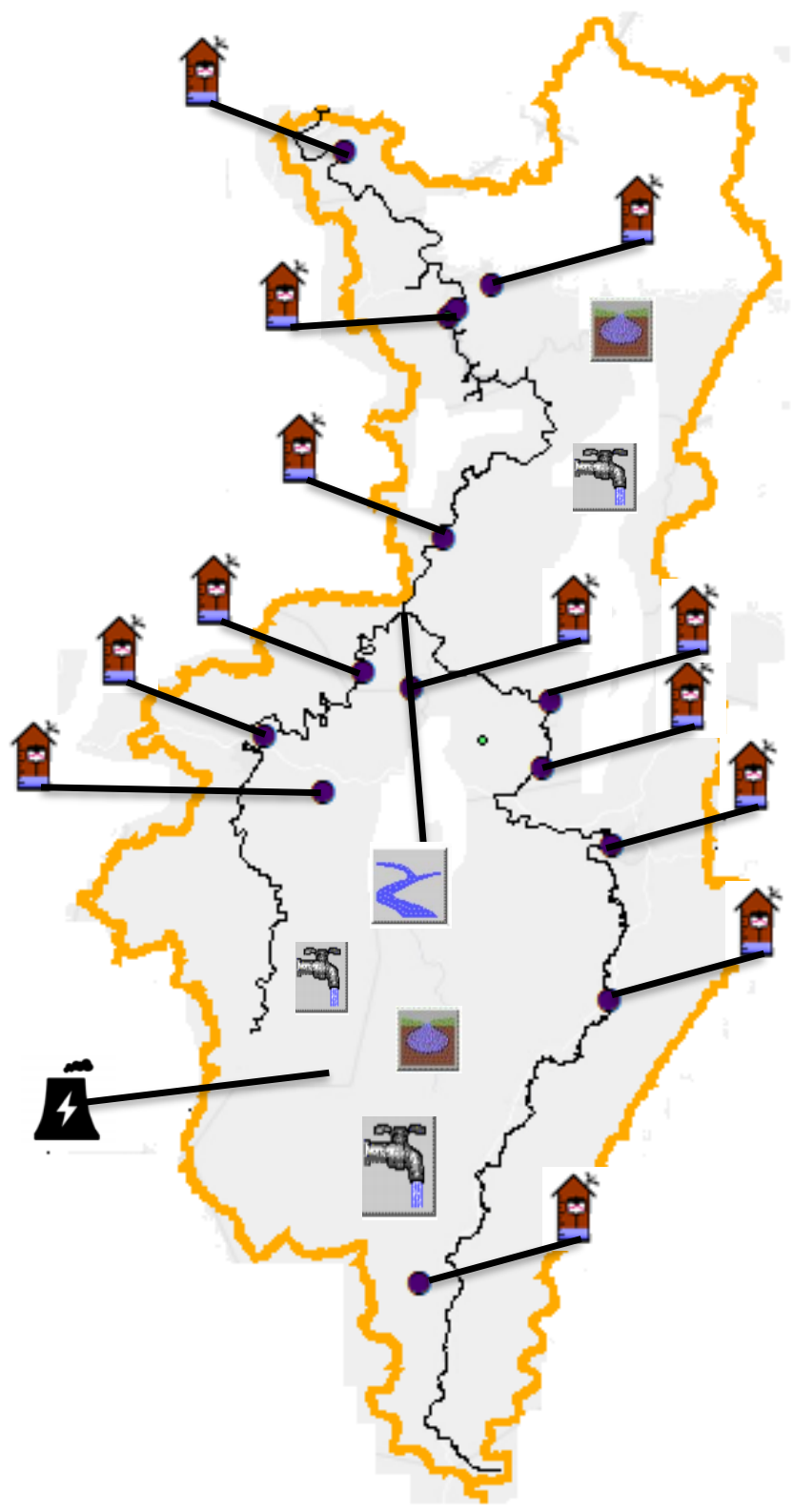

\section{Legend:}

ff Stream Gage

2 Confluence

4 Power Plant Diversion

Water User

5. Ground Water

Figure 2. Representation of data flow for RiverWare software 


\subsection{Conclusion}

This paper discusses the merits of five different river basin modeling software's with the conclusion that RiverWare would be the most appropriate choice for West Virginia. Given currently available data that is open to the public, a basic model could be started, more than likely as a calibration check to determine if the model setup accurately reflects historical data. Additional information will be needed to create a river basin model for the Tygart Valley watershed that could be used as planning tool for the area. Groundwater storage would be the first piece of information recommended to obtain. Beyond this, more stream gauges and effective information on large quantity users that is more recent will be important to add so that the accuracy of the model is present. As more data is provided to the model the more substantial of an impact it will have on the effective and efficient usage of water. 


\section{Chapter 4. References}

Abudu, S., Sheng, Z., Sabzi, H. Z., and King, J. P. 2018. "Drought Scenario Analysis Using RiverWare: A Case Study in Urumqi River Basin, China.” Civil Engineering Journal, 4(8), 1837-1850.

AECOM and BOYLE. 2012. "Colorado River Water Availability Study” Accessed October $12,2019$. https://usace.contentdm.oclc.org/digital/api/collection/p16021coll7/id/4113/download

Bailey, J., and Wirts, J. 2003. "The Ecological Assessment of the Tygart Valley River Watershed" https://dep.wv.gov/WWE/watershed/wqmonitoring/Documents/EcologicalAssessmen ts/EcoAssess_Tyg_2003.pdf

Colorado Divison of Natural Resources (Colorado DNR). n.d. "OpenCDSS / StateMod." StateMod. Accessed August 24, 2019. http://learn.openwaterfoundation.org/cdsswebsite-opencdss/statemod/statemod/

Colorado State University. 2017. "What is Modsim-DSS?” MODSIM-DSS. Accessed November 18, 2019. http://modsim.engr.colostate.edu/index.shtml

Clemson Public Service and Agriculture. n.d. "Water Modeling." Clemson Public Service and Agriculture. Accessed August 28, 2019. https://www.clemson.edu/public/waterassessment/model.html

Diaz, G. E., Brown, T. C., and Sveinsson, O. 2019. “Aquarius: A Modeling System for River Basin Water Allocation." Social and Economic Values in Natural Resource Planning. Accessed September 20, 2019. https://www.fs.fed.us/rm/value/aquarius\#modeldescr

Dinar, A., Dinar, S., McCaffrey, S., and McKinney, D. 2007. "Bridges over water: understanding transboundary water conflict, negotiation and cooperation." World scientific, New Jersey.

George, B., Malano, H., and Davidson, B. 2019. “'Integrated Water Allocation-Economic Modeling at a Catchment Scale.” https://pdfs.semanticscholar.org/e7fe/35da266d8598c01e93e743b99eb3ba044 470.pdf

HydroLogics. n.d. "OASIS Software.” HydroLogics. Accessed September 11, 2019. https://www.hydrologics.net/oasis-software 
HydroLogics. 2009. "User Manual for Oasis with OCL." HydroLogics. Accessed October 2, 2019. https://docs.wixstatic.com/ugd/40e8d2_372b277e8dc34177ae9a5e231e56441d.pdf

Hyun, J.-Y. E., Huang, S.-Y. E., Yang, Y.-C. E., Tidwell, V. E., and Macknick, J. E. 2019. "Using a coupled agent-based modeling approach to analyze the role of risk perception in water management decisions." Hydrology and Earth System Sciences, 23(5), 2261-2278.

Libes, S. n.d. "AQUARIUS Water Quality.” AQUARIUS informatics. Accessed October 20, 2019. https://aquaticinformatics.com/files/coastal-carolina-aquarius-time-series-aicase-study.pdf

Macpherson, B. 2016. "A Comparison of RiverWare and StateMod as Water Allocation Model Platform." RiverWare. Accessed August 15, 2019. https://riverware.org/riverware/ugm/2016/PDFs/Users/Macpherson_RiverWare and StateMod presentation.pdf

Nature Conservancy 2018. "Building a Hydrologic Foundation." The Conservation Gateway: The Nature Conservancy. Accessed August 24, 2019. https://www.conservationgateway.org/ConservationPractices/Freshwater/Environmen talFlows/MethodsandTools/ELOHA/BuildingaHydrologicFoundation/Pages/buildinghydrologic-found.aspx

O’Leary, S. 2019. "The Where and the How of West Virginia's Population Decline" Accessed November 5, 2019. https://wvpolicy.org/the-where-and-the-how-of-westvirginias-population-decline/

Parker, R., Leavesley, G., Vaccaro, J., Fulp, T., and Frevert, D. 2006. "Watershed and River Systems Management Program: Overview of Capabilities.” J. Irrig and Drain. Engrg., 132(2), 92-97

Qiu, J., Yang, Q., Zhang, X., Huang, M., Adam, J. C., and Malek, K. 2019. “Implications of water management representations for watershed hydrologic modeling in the Yakima River basin." Hydrology and Earth System Sciences, 23(1), 35-49.

RiverWare, 2015. “Applications.” RiverWare. Accessed September 25, 2019. http://www.riverware.org/riverware/applications.html 
South Carolina Division of Natural Resources (DNR). n.d. "Simplified Water Allocation Model Version 4.0 User's Manual." South Carolina DNR. Accessed October 5, 2019. http://www.dnr.sc.gov/water/waterplan/swmpdfs/TechnicalReports/SWAMusermanv 4dot0.pdf

South Carolina Division of Natural Resources (DNR). n.d. "Simplified Water Allocation Models (SWAM)." South Carolina Department of Natural Resources. Accessed August 28, 2019. http://www.dnr.sc.gov/swam-models/index.html

Smith, C. D. M. 2017A. “South Carolina Surface Water Quantity Models Edisto Basin Model.” Accessed October 24, 2019. http://hydrology.dnr.sc.gov/swammodels.html\#download-models

Smith, C. D. M. 2017B. "South Carolina Surface Water Quantity Models Saluda River Basin Model.” Accessed October 24, 2019. http://hydrology.dnr.sc.gov/swammodels.html\#download-models

South Carolina Division of Natural Resources. 2018. "Surface Water (StateMod)." Colorado's Decision Support Systems. Accessed August 15, 2019. https://www.colorado.gov/pacific/cdss/surface-water-statemod

Streamlined Environmental. n.d. "SWAN- Simplified Water Allocation Model." Accessed August 28, 2019. https://streamlined.co.nz/wp-content/uploads/2019/03/4760SWAM-Case-Study-P2.pdf

U. S. Army Corp of Engineers (USACE). 2019. "West Virginia National Inventory of Dams." National Inventory of Dams (NID) - Home. Accessed November 15, 2019. https://nid.sec.usace.army.mil/ords/f?p=105:18:8085477432675::NO:::

U.S. Army Corps of Engineers (USACE). 2016. "Engineering and Design WATER CONTROL MANAGEMENT.” USACE, ER 1110-2-240

U.S. Army Corps of Engineers (USACE). 1992. "Drought Contingency Plan for Tygart Lake West Virginia." USACE

U.S. Environmental Protection Agency (USEPA). 2016. "What Climate Change Means for West Virginia.” EPA, 430-F-16-050. https://19january2017snapshot.epa.gov/sites/production/files/201609/documents/climate-change-wv.pdf 
U.S. Geological Survey. USGS. 2019A. "MODSIM-DSS.” USGS Science for a changing world. Accessed November 18, 2019. https://www.usgs.gov/modsim-dss

U.S. Geological Survey. USGS. 2019B. “USGS Water Resources Links for: 05020001 Tygart Valley." USGA Science for a changing world. Accessed November 21, 2019. https://water.usgs.gov/lookup/getwatershed?05020001

U.S. Geological Survey. USGS. 2019C. “Current Conditions for West Virginia: Streamflow - 202 site(s) found." USGA Science for a changing world. Accessed November 21, 2019. https://waterdata.usgs.gov/wv/nwis/current/?type=flow

U.S. Geological Survey. USGS. 2019D. "USGS Water Data for the Nation.” USGA Science for a changing world. Accessed November 18, 2019. https://waterdata.usgs.gov/wv/nwis/current/?type=flow

Weiss, J. W., Palmer, R., Balay, J., and Howells, C. n.d. "Sectoral Applications Research Program (SARP) Final Report.” Susquehanna River Basin Commission, Accessed October 17, 2019. https://www.srbc.net/our-work/programs/planningoperations/docs/drought-forecasting-planning-chesapeake.pdf

West Virginia Department of Environmental Protection (WV DEP). 2009. Hydrologic unit Code (HUC 8) 8-Digit Watersheds. WV DEP.

West Virginia Department of Environmental Protection (WV DEP). 2013. WV Watersheds A Closer Look. WV DEP.

Xie, H., Shen, Z., Chen, L., Lai, X., Qui, J., Wei, G., Dong, J., Peng, Y., and Chen, X. 2019. "Parameter Estimation and Uncertainty Analysis: A Comparison between Continuous and Event-Based Modeling of Streamflow Based on the Hydrological Simulation Program-Fortran (HSPF) Model.” MDPI. Water 2019, 11(1), 171

Zagona, E. A., Fulp, T. J., Shane, R., Magee, T., and Goranflo, H. M. 2001. "RiverWare: A Generalized Tool For Complex Reservoir System Modeling1.” JAWRA Journal of the American Water Resources Association, 37(4), 913-929. 


\section{APPENDIX}

- Storage Reservoir: "A reservoir with Release and spillways and no hydropower facilities. Storage is a function of Pool Elevation as defined by an Elevation-Volume Table." (RiverWare 2015)

- Pumped Storage: "A reservoir which has reversible pump-turbines. The turbines may generate or pump at each time step. Storage is a function of Pool Elevation as defined by an Elevation-Volume Table." (RiverWare 2015)

- River Reach: "A river section which routes water using one of many possible routing algorithms. Reaches may lose water to a Diversion and gain water from Return Flow. Reaches can also have side inflows, gains, and/or losses." (RiverWare 2015)

- Aggregate Reach: "An aggregate object which contains one or more Reach objects." (RiverWare 2015)

- Control Point: "An object used to regulate upstream reservoirs so that channel capacity at the control point is not violated." (RiverWare 2015)

- Inline Power: "An object used to model power production on a stretch of reach with no storage (run of river power production)." (RiverWare 2015)

- Canal: "A bi-directional conveyance channel which delivers water by gravity between two Reservoirs.” (RiverWare 2015)

- Pipeline: "An object that models flow in a pipeline between two objects." (RiverWare 2015)

- Pipe Junction: "An object used with pressurized flow to split flows similar to a bifurcation or bring flows together similar to a confluence." (RiverWare 2015)

- Inline Pump: “An object used to model a booster pump station. It controls solution direction, calculates added head and calculates the power consumed." (RiverWare 2015)

- Aggregate Distribution Canal: "An aggregate object which serves to route Diversion Requests from a Water User upstream to a Diversion object. It also routes flow from the Diversion object down to the Water Users. The Aggregate Distribution Canal contains Distribution Canal element object." (RiverWare 2015)

- Diversion: "An object which diverts water from a Reservoir or Reach. The amount of water which may be diverted is based on water surface elevation, pumping parameters, or available water." (RiverWare 2015)

- Water User: "An object that diverts water from a Reach or a Reservoir, consumes water, and then returns excess flow to the system." (RiverWare 2015)

- Ground Water Storage: "An underground storage reservoir which receives Inflow from Water User Return Flow or Reach seepage and can return water to the system." (RiverWare 2015)

- Aquifer: "A deep, fully saturated, often confined groundwater system. This object can solve at the run time step or a user-selectable larger computational time step.

- Stream Gage: An object used to represent stream gage location. It shows the discharge data at a particular location in a model." (RiverWare 2015)

- Thermal Object: "An object which models the economics of the thermal power system and the thermal replacement value of the hydropower." (RiverWare 2015)

- Data Object: "A container for custom slots and user defined data that is not appropriate on a simulation object." (RiverWare 2015) 
- Operational Rules: "Simulates a wide variety of operating agreements and exchanges between one or more structures." (RiverWare 2015)

- Daily or Monthly Time Step: "Simulates in a monthly or daily time step. For a daily simulation, input data requirements may be simplified by allowing the user to: 1 . Provide daily data, 2. Estimate daily data by requesting the model divide a monthly value by the number of days in a month, 3 . Estimate daily data by requesting the model use a monthly average, or 4. Estimate daily data by requesting the model use monthly data and another gages daily distribution. Daily base flow data may be developed directly or estimated from monthly base flow estimates." (RiverWare 2015) 